\title{
Belgeo
}

Revue belge de géographie

$4 \mid 2003$

The dynamics of metropolisation : from words to territory

\section{P. Degroote, V. Truwant, Demografie en samenleving}

Universitaire Pers, Leuven, 2003

\section{H. Keeris}

\section{(2) OpenEdition}

\section{Journals}

Electronic version

URL: http://journals.openedition.org/belgeo/16873

DOI: 10.4000/belgeo.16873

ISSN: 2294-9135

Publisher:

National Committee of Geography of Belgium, Société Royale Belge de Géographie

Printed version

Date of publication: 30 December 2003

ISSN: 1377-2368

\section{Electronic reference}

H. Keeris, « P. Degroote, V. Truwant, Demografie en samenleving », Belgeo [Online], 4 | 2003, Online since 15 February 2016, connection on 24 September 2020. URL : http://journals.openedition.org/belgeo/ 16873 ; DOI : https://doi.org/10.4000/belgeo.16873

This text was automatically generated on 24 September 2020.

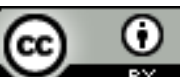

Belgeo est mis à disposition selon les termes de la licence Creative Commons Attribution 4.0 International. 


\section{P. Degroote, V. Truwant, Demografie en samenleving}

Universitaire Pers, Leuven, 2003

H. Keeris

\section{REFERENCES}

P. Degroote, V. Truwant V., Demografie en samenleving, Universitaire Pers, Leuven

1 Dit omvangrijke boek (445 p.) richt zich tot een ruim lezerspubliek en tracht op een duidelijke en eenvoudige wijze de verschillende demografische gegevens en begrippen te definiëren.Daarbij wordt aansluitend gebruik gemaakt van uitvoerig verwerkte statistische gegevens. Dit wetenschappelijk basiswerk is daardoor uitgegroeid tot een interessante informatiebron met soms uitvoerige details.

2 Na een inleidend hoofdstuk worden achtereenvolgens behandeld: het demografische bronnenmateriaal, de nataliteit, de nuptialiteit en samenlevingsvormen, de mortaliteit, de bevolkingsgroei en -projecties, de structuur van de bevolking, beleidsrelevante vraagstukken met betrekking tot de demografie, de evolutie van de wereldbevolking en de diverse migratoire bewegingen.De sociale aspecten die met dit alles verband houden krijgen tevens de nodige aandacht.Zo komst zelfs het asielbeleid breedvoerig aan bod. De auteurs hebben bovendien gebruik gemaakt van zeer recent bronnenmateriaal, waarbij vooral aandacht wordt besteed aan Belgische en Nederlandse gegevens.Bij de bespreking van de reproductie of vervanging wordt slechts melding gemaakt van Lotka, terwijl de methode voor Kuczynski niet vermeld wordt.Enkele schoonheidsfouten ontsieren - in dit voor het overige keurige werk - de tekst.

3 Aldus is de bepaling van vruchtbaarheid niet correct (p.65) evenals dit van bruto immigratiecijfer (p. 271).Dit geldt ook voor enige nalatigheden of drukfouten.Dit alles doet echter niets af aan de waarde van het boek, dat uitermate geschikt is om te gebruiken als documentatiebron bij de studie van thema's inzake 
bevolkingsgeografie.Een uitgebreid trefwoordenregister, vocabularium en talrijke figuren en tabellen maken er een nuttig en handzaam werk van. 